AUTHOR:

Paul F. Bandia ${ }^{1}$

AFFILIATION:

${ }^{1}$ Concordia University

EMAIL:

paul.bandia@concordia.ca

DOI: https://doi.org/10.38140/

jtsa.1.4333

Journal for Translation

Studies in Africa

2020 (1): 59-62

PUBLISHED:

22 May 2020

Published by the UFS

http://journals.ufs.ac.za/index.php/itsa

(-) Creative Commons

With Attribution (CC-BY)

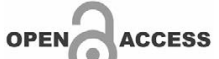

\section{A TRANSLATION TURN IN AFRICA}

Once considered merely as a subfield of the science of linguistics, translation studies has earned its droit de cité, that is, the right to exist as an autonomous discipline. Having shed its linguistic confines, translation studies has been growing in leaps and bounds, owing to an ever-increasing cross-fertilisation process involving many other established academic disciplines. The term "translation" is no longer the preserve of theorists and practitioners of translation but has taken on a slew of meanings and connotations that may vary according to the perspectives of the host disciplines. As a concept, "translation" is generally understood in its pragmatic dimension as the transfer between languages and cultures, yet the term has increasingly taken on a metaphorical acceptation that may go beyond the usually implied linguistic exchange. Although opinions may vary, it is generally agreed that this development has been beneficial to the field of translation studies by expanding its horizons and elevating scientific inquiry to new heights. Gone are the days when translation studies research was conveniently located within applied linguistics and mainly concerned with linguistic and semantic equivalency between language cultures studied from the perspective of comparative stylistics. In addition, passé is the application of translation in philology as a means of literary apprenticeship or as a pedagogical strategy for learning foreign languages. Today's full-blown and multifaceted conceptualisation of translation is largely due to what is historically known as the "cultural turn" in translation studies, which in the 1990s pushed the boundaries of inquiry from mainstream preoccupation with dominant language cultures to include marginalised or peripheral language cultures that were often side-lined in global discourses on knowledge-making. Incongruously referred to as minority language cultures, some of the marginalised contexts often included large swathes of the regions of the world that happened to have been under Western colonisation or imperialism. Included here is the entire continent of Africa, which happens to be larger in geographic size than Europe and is home to myriads of languages and cultures, some dating back to ancient or prehistoric times. Given its Eurocentric antecedent, the "cultural turn" in translation studies, while enabling the study of once-overlooked areas such as Africa, unfortunately left 
the impression that translation activity on the continent worth studying began with Western colonisation to the detriment of an interest in indigenous translation activity in prehistoric or precolonial Africa. Hence the predominance of postcolonial theory or approaches to the study of translation in Africa.

There have been attempts at studying translation phenomena on the continent in relation to indigenous practices that predate colonisation, mainly in the context of intermediality between orality and writing. The development of indigenous alphabets or writing systems before colonisation and the use of drum language as a translation medium have opened up insights into locally derived knowledge on African translation theory and practice. The study of the role of the griot or storyteller who, by inheritance, is at once the repository and conveyor of the history and folklore of his people as well as the study of the role of "court linguist" especially endowed with the authority and gift to be the mouthpiece, or go-between, or interpreter of the king's esoteric language for the benefit of the people are also indications of precolonial translation thought and practices. One can also mention the abundance of literature evidencing a rich history of indigenous translation thought and practices in the Horn of Africa based on sophisticated and well-established ancient languages and literary systems. These are quintessentially African modes of translation that are yet to be explored fully but whose development has been stunted by the predominance of (post-)colonial preoccupations. Colonial translation practice in Africa is largely characterised by the imperialist need to decipher and capture in writing the imaginary, logos and essence of the colonised in order to ensure better control and dominance. Colonial translation practice would also serve the purposes of holding up what was conceived as African primitivity against Western enlightenment, a sort of feel-good strategy to achieve gratification by comparing and contrasting so-called premodern societies to Western societies on the basis of Western enlightenment and modernity. There was also the desire to involve Africa in the inevitable universal march towards the ideals of Western civilisation. It is no coincidence therefore that most translations carried out at the time were by Christian missionaries with the aim of proselytising and by colonial administrators, linguists and anthropologists, all in a bid to enable or facilitate colonial governmentality. There were translations from African indigenous languages into European colonial languages as well as translations of European classics into African languages, particularly into African languages of wider communication such as the lingua franca Swahili. Other translations into African languages were encouraged to prove the viability of said languages for expressing complex ideas in line with testing the limits of a Sapir-Whorfian hypothesis regarding the interplay between language, thought and worldview.

The struggle for liberation and independence of the colonies saw the rise of anti-colonial movements such as Negritude and Pan-Africanism, which for the most part sought to extoll the virtues of Africanity by expressing African thought and artistry in colonial languages in order to impress upon the coloniser the wealth of African civilisation and to buttress the demand for independence. The anti-colonial endeavours laid the groundwork for what, after independence, was to become in the English-speaking world the postcolonial paradigm of study aimed at countering imperialist conceptualisations of formerly colonised societies. I say "English-speaking world" because, despite the great efforts of the francophone Negritude movement, it is generally well known that postcolonialism as a concept was never quite embraced by France whose relationship with the colonies was pursued and maintained through a policy of assimilation. Nonetheless, the contribution of postcolonial writers and thinkers in the francophone world has been significant and instrumental in undermining the 
continued imperialist designs of the West on former colonial territories. Postcolonial theory has been the overriding force behind the assertion of African modernity. The theory has been drawn on by scholars with an interest in Africa from a variety of disciplines, including history, anthropology, sociology, linguistics, fine arts and literature, to name a few. It is mainly thanks to postcolonial theory and approaches that the field of translation studies has seen an exponential growth in research and scholarship, postcolonial theory here defined loosely to include most marginalised conditions (e.g. gender, sexual orientation, ethnicity and indigenous rights) especially at the intersection with cultural studies and postmodernism. By the same token, translation studies in or about Africa has established its space in the academic field of translation studies mainly through the exploitation of postcolonial theory and discourse. Although the bulk of African translation research has been on literary productions (which is not that different from the experience of most other traditions or cultures), the study of the writing and translation of postcolonial African literature has undeniably asserted African identity and presence within the global literary and cultural marketplace. It is interesting to note how much other marginalised cultures have drawn from African postcolonial translation theory and discourse to explore their own particular situations and recount their specific translation histories. It is also important to point out that not all explorations of African postcoloniality have been from a literary perspective. There are indeed several non-literary translation-related studies on or about Africa that also draw from postcolonial theory.

It is therefore unseemly to address one's ire or misgivings about literary scholarship by insinuating that postcolonial theory is alien to the real preoccupations of the African continent and that a literary perspective is too lofty and highbrow for the down-to-earth needs and expectations of the continent. Indeed, postcolonial theory has been an equal opportunity enabler of resentment. On the one hand, some Western scholars feel threatened by it and see it as a kind of Trojan horse whose main purpose is to evoke guilt and undermine Western (classical) scholarship and elevate subaltern views over Western thought. On the other hand, there are those scholars in former colonies who are dismissive or suspicious of postcolonial theory, perceiving it as the cunning creation of Western scholarship aided by postcolonial subjects living in the West with an entirely Western perspective designed to maintain control over scholarship in former colonies. For some of these sceptics, postcolonial theory is almost entirely informed by Western (postmodern) thought with hardly any input from the former colonies. What is more, postcolonial subjects in the halls of Western academia engaged in postcolonial theory are seen as lost souls in the diaspora struggling to cope with the ills of their minority condition in a predominantly European context. This perception or feeling is often enhanced when a scholar in a former colony is embraced by a scholar of European descent who is largely resentful of postcolonial scholarship. A curious situation arises reminiscent of colonial relations where the home-based scholar is more eager to collaborate with the European scholar than with the postcolonial subject in the diaspora. Either way, postcolonial theory and its practitioners in the diaspora are considered suspect and therefore tend to bear the brunt of the lasting effects of colonialism. As a discipline, postcolonial translation studies has not been spared the ordeal of this general attitude. It is interesting to recall how popular postcolonial theory was in the early days, with numerous scholars from the global South and the global North riding the wave. Many books, articles and essays were published; book series and research projects were launched. Postcolonial theory was drawn upon indiscriminately to account for minority conditions or situations of power imbalance in various contexts, including Western societies. Then there was a decline in interest followed by unwarranted criticism, revealing of a kind of frustration in some quarters with not feeling in total control of the subject 
matter for lack of the relevant lived experience. Like most theories, postcolonial theory has its limitations, of course, but its contribution to the advancement of knowledge in translation studies cannot be denied.

More recently, there has been a shift in focus concerning what can be referred to as the postcolony. This implies a centripetal approach where the emphasis is on the daily lives of people in former colonies or the lived experience within the postcolony itself. This is an interesting and welcome turn of events, as there is a dire need to encourage translation research, scholarship and practice within the continent. I, for one, have pursued this line of inquiry by looking into literature based on contemporary reality or lived experiences on the continent, knowing full well that literary fiction often mirrors the lived experience of the fictionalised characters and context. What transpires is a unique situation where power relations are often internal (the dynamics of class, power and inequality within the postcolony) rather than external (as was the case between the colony and the métrople). It would be imprudent to dismiss literary fiction in this current research paradigm (because of its so-called lofty ideals supposedly disconnected from the reality on the ground) as fiction is known to be one of the most potent means of denouncing abuses of power, corruption, autocracy and plutocracy. It also lays bare the underlying narratives that can enlighten one on the reasons for the persistent hardships and obstacles and point the way forward towards sustained development. Other avenues in this line of inquiry that privileges the postcolony are being developed, especially the research area that combines development studies and translation theory. Others yet are highlighting the importance of encouraging and studying translation in African indigenous languages. The latter have indeed fared poorly under the influence of postcolonial approaches, which have depended heavily on writings in former colonial languages. Also, the realm of translation within the postcolony features research in the general area of community translating, including health services, refugees and asylum seekers, war and conflict resolution, truth and reconciliation commissions, among other topics. Having the spotlight on the postcolony itself is bound to enrich translation research on or about the continent and bring into the fold researchers with diverse backgrounds and interests.

The launching of this journal is quite timely as it is destined to become an indispensable forum for disseminating translation research and knowledge on or about the African continent and its diaspora. In the last few years, there have been several doctoral dissertations with a focus on translation in Africa. The future looks bright, and the possibilities seem limitless in the current state of affairs. 